\title{
Interaction of Small Zinc Complexes with Globular Proteins and Free Tryptophan
}

\author{
Joann M. Butkus, ${ }^{1}$ Shelby O'Riley, ${ }^{1}$ Balwant S. Chohan, ${ }^{2}$ and Swarna Basu' \\ ${ }^{1}$ Department of Chemistry, Susquehanna University, 514 University Avenue, Selinsgrove, PA 17870, USA \\ ${ }^{2}$ Math \& Natural Sciences Department, Centenary College, 400 Jefferson Street, Hackettstown, NJ 07840, USA \\ Correspondence should be addressed to Swarna Basu; basu@susqu.edu
}

Received 19 October 2015; Revised 21 December 2015; Accepted 29 December 2015

Academic Editor: Shigehiko Takegami

Copyright ( 2016 Joann M. Butkus et al. This is an open access article distributed under the Creative Commons Attribution License, which permits unrestricted use, distribution, and reproduction in any medium, provided the original work is properly cited.

A series of eight water soluble anionic, cationic, and neutral zinc(II) complexes were synthesized and characterized. The interaction of these complexes with bovine serum albumin (BSA), human serum albumin (HSA), lysozyme, and free tryptophan (Trp) was investigated using steady-state fluorescence spectroscopy. Static and dynamic fluorescence quenching analysis based on SternVolmer kinetics was conducted, and the decrease in fluorescence intensity of the Trp residue(s) can be ascribed predominantly to static quenching that occurs when the $\mathrm{Zn}$ complex binds to the protein and forms a nonfluorescent complex. The role played by the nature of the ligand, the metal, and complex charge in quenching Trp fluorescence was investigated. The binding association constants $\left(K_{a}\right)$ ranged from $10^{4}$ to $10^{10} \mathrm{M}^{-1}$ and indicate that complexes with planar aromatic features have the strongest affinity for globular proteins and free Trp. Complexes with nonaromatic features failed to interact with these proteins at or in the vicinity of the Trp residues. These interactions were studied over a range of temperatures, and binding was found to weaken with the increase in temperature and was exothermic with a negative change in entropy. The thermodynamic parameters suggest that binding of $\mathrm{Zn}$ complexes to the proteins is a highly spontaneous and favorable process.

\section{Introduction}

Zinc(II) is one of the most important metal ions found in proteins and metalloenzymes, including alcohol dehydrogenase, carbonic anhydrase, carboxypeptidase A, matrix metalloproteinase, and thermolysin [1-5]. Zinc proteins play a vital role in the biosynthesis and metabolism of a number of bioactive peptides and have been implicated in various disease states including cancer, arthritis, and multiple sclerosis [6].

Structurally, biological zinc is found ligated by a shell of hydrophilic side chains, involving $\mathrm{O}, \mathrm{N}$, and $\mathrm{S}$ donors, in 4-, 5-, or 6-coordinate geometry. The most common donor protein-derived ligands tend to be His, Cys, Asp, Glu, and water molecules. This hydrophilic shell is often embedded within a larger shell made up of hydrophobic side chains [79]. Regardless of the common qualitative features of the $\mathrm{Zn}$ binding site, much effort has been devoted to understanding the role of the specific pattern of $\mathrm{Zn}$ ligation and the protein matrix in regulating reactivity.
Albumin proteins bind and transport a wide diversity of ions and molecules with very high affinity [10-13]. Human serum albumin (HSA) accounts for $60 \%$ of serum proteins and is the most abundant protein in the circulatory system [14-17]. Bovine serum albumin (BSA) is a homologous globular protein and its sequence is $76 \%$ identical to that of HSA. For many drugs and exogenous metal complexes, binding to serum albumin is a critical determinant of their distribution, pharmacokinetics, and potency [18-20].

In this work, several small $\mathrm{Zn}$ (II) complexes with varying $\mathrm{O}, \mathrm{N}$, and $\mathrm{S}$ donor ligands, including some that are novel, were synthesized and characterized. The interaction of these complexes with BSA, HSA, lysozyme, and free tryptophan (Trp) was investigated using steady-state fluorescence spectroscopy to gain information on the binding mode, binding order, affinity, efficiency, and mechanism of fluorescence quenching. The information could potentially lead to better structure-based drug design and development of highly selective ligands as tags for precise and accurate quantification of 
proteins, which will ultimately lead to new and more effective therapeutic approaches [21, 22].

The dominant fluorophore in these proteins is Trp, a residue that has an emission maximum that is sensitive to the polarity of the surrounding environment. HSA contains 585 amino acids, with a single intrinsic Trp residue at position 214. BSA consists of a chain of 580 amino acids, with two Trp residues at positions 134 and 212. Fluorescence quenching constants and thermodynamic parameters $(\Delta H, \Delta S$, and $\Delta G)$ for the interaction were calculated using Stern-Volmer kinetics and a Van't Hoff analysis.

The interaction of $\mathrm{Zn}$ complexes with lysozyme is included since it is a very well characterized protein, containing six Trp residues that are located in the substrate binding sites and are essential for enzymatic activity. It is expected that each of the Trp residues will be affected differently depending on their location and environment and so contributing independently to the inherent fluorescence intensity [23-30]. Steady-state fluorescence studies have shown that most of the lysozyme emissions are due to Trp-62 and Trp-108, residues that are buried deep in the active site [26, 30]. Lysozyme has many physiological and pharmaceutical functions, one of which is to bind and transport drugs. The inclusion of free Trp is to illustrate the affinity of the $\mathrm{Zn}$ complexes for this particular amino acid, with its indole functional group, irrespective of the surrounding environment. The experimental results have allowed us to discuss the type, degree, and nature of the interactions taking place between the protein and the $\mathrm{Zn}$ complexes, with particular consideration to polarity, hydrophobicity, and molecular charge.

\section{Experimental}

2.1. Materials and Methods. Unless otherwise mentioned, all chemicals and reagents were of analytical grade (SigmaAldrich, Alfa Aesar, TCI, VWR). The solvents either were HPLC-grade or were dried and distilled using conventional methods and stored under an argon atmosphere [31, 32]. Nanopure water was used for all of the experiments. $\mathrm{Zn}$ (II) complexes are relatively stable in air; however, many of the ligands are air/moisture sensitive; therefore, all synthetic procedures were conducted using Schlenk techniques, and by default all compounds were stored in sealed vials under argon. The three proteins and free Trp were purchased (Sigma-Aldrich) and used without further purification. Stock solutions of proteins, Trp, and the $\mathrm{Zn}$ complexes were prepared in $50 \mathrm{mM}$ Tris- $\mathrm{HCl}$ ( $\mathrm{pH}$ 7.4) buffer solution.

2.2. Physical Measurements. FTIR data for solid samples (as $\mathrm{KBr}$ disks) and neat liquid samples were obtained on a Jasco 4000 IR spectrometer. The IR spectral peaks were calibrated with polystyrene and are reported in wavenumbers. Relative intensities of the key bands in a spectrum are indicated ( $\mathrm{w}=$ weak, $\mathrm{m}=$ medium, $\mathrm{s}=$ strong, $\mathrm{vs}=$ very strong, and br = broad). Elemental analyses were performed at the UMass-Amherst Microanalysis Center, or by QTI/Intertek, Whitehouse, NJ. Samples for microanalysis were ground to a fine powder and vacuum desiccated over phosphorus pentoxide for at least four days prior to analysis. UV-vis experiments for characterization of the $\mathrm{Zn}$ complexes and determination of protein concentration were carried out using a Cary 4000 UV-vis spectrophotometer. Fluorescence spectra were obtained at room temperature using a PerkinElmer LS50B Spectrometer. The fluorescence emission spectra were corrected for wavelength dependent sensitivity using a calibration curve that was generated using five commercial spectral fluorescence standards (BAM-F001 to F005, SigmaAldrich) [33].

For the fluorescence quenching experiments, the concentration of the protein, or free Trp, was held constant at $0.1 \mu \mathrm{M}$ and the concentration of each $\mathrm{Zn}$ complex was varied from $0 \mu \mathrm{M}$ to $21.0 \mu \mathrm{M}$, via preparation of individual samples. The concentration range was adjusted according to whether quenching was more clear at higher or lower concentrations. The excitation wavelength was $280 \mathrm{~nm}$, the emission wavelength was $345 \mathrm{~nm}$ for the proteins and $363 \mathrm{~nm}$ for Trp, and both the excitation and emission slit widths were kept constant at $4.0 \mathrm{~nm}$. Fluorescence spectra were obtained at $25^{\circ} \mathrm{C}, 35^{\circ} \mathrm{C}$, and $45^{\circ} \mathrm{C}$. Spectra have been smoothed for presentation purposes.

2.3. Data Analysis. The dynamic quenching constants were determined using the Stern-Volmer relationship as shown in the following equation $[24,34]$ :

$$
\frac{F_{0}}{F}=1+K_{\mathrm{SV}}[Q]
$$

where $F_{0}$ and $F$ correspond to the fluorescence intensities of the protein in the absence and presence of quencher, respectively. [Q] is the concentration of the quencher. $K_{\mathrm{SV}}$ is the Stern-Volmer quenching constant. $K_{\mathrm{SV}}$ is related to the lifetime of the system according to the following equation:

$$
K_{\mathrm{SV}}=k_{q} \tau_{0}
$$

where $k_{q}$ is the bimolecular quenching constant and $\tau_{0}$ is the lifetime of unquenched fluorophore. The value of $\tau_{0}$ is short for free $\operatorname{Trp}(2.7 \mathrm{~ns})$ but longer in a protein environment. This value is dependent on the location within the protein, the extent of solvent exposure, and the vicinity of various side chains [35-37]. The static quenching constant, also known as the binding constant, $K_{a}$, and binding site number, $n$, were calculated from the following equation $[24,34]$ :

$$
\log \left[\frac{F_{0}-F}{F}\right]=\log K_{a}+n \log [Q] \text {. }
$$

The change in Gibb's free energy, $\Delta G$, was calculated using (4), where $R$ is the gas constant and $T$ is the temperature (K). Changes in entropy $(\Delta S)$ and enthalpy $(\Delta H)$ were determined using Van't Hoff plot, based on the following:

$$
\begin{gathered}
\Delta G=-R T \ln K_{a}, \\
\ln K=-\frac{\Delta H}{R T}+\frac{\Delta S}{R} .
\end{gathered}
$$

Finally, the possibility of Forster type long-range energy transfer (FRET) from the Trp residues was explored using previously published protocols, and the Forster distances, $R_{0}$, were calculated using the relevant spectroscopic properties of the participating molecules [38, 39]. 
2.4. Synthesis and Characterization of Zn Complexes. A series of eight water soluble $\mathrm{Zn}$ (II) complexes with varying donor atoms and ligand types were synthesized.

Complex 1, $\mathrm{Na}_{2}[\mathrm{Zn}(\mathrm{EDTA})] \cdot 2 \mathrm{H}_{2} \mathrm{O}$, Zinc(II) Ethylenediaminetetraacetate Disodium Dehydrate. The zinc salt was synthesized in a slightly modified manner to that reported in the literature [40]. $\mathrm{Na}_{2}($ EDTA $) \cdot 2 \mathrm{H}_{2} \mathrm{O}(10.83 \mathrm{~g}, 29.1 \mathrm{mmol})$ dissolved in $50 \mathrm{~mL}$ of water was added to a solution of $\mathrm{ZnCl}_{2}$ (3.96 g, $29.1 \mathrm{mmol}$ ) dissolved in $30 \mathrm{~mL}$ of water. The solution was neutralized by adding $4.89 \mathrm{~g}(58.2 \mathrm{mmol})$ of $\mathrm{NaHCO}_{3}$ and then adjusted to $\mathrm{pH} 7.0$ with a few drops of $3 \mathrm{M} \mathrm{HCl}$ and heated to $80^{\circ} \mathrm{C}$ for $5 \mathrm{~min}$. The solution was then left to concentrate in the open air at room temperature overnight. Addition of $20 \mathrm{~mL}$ of absolute ethanol produced a white colored crystalline material which was filtered and dried in vacuo for two days. The product was recrystallized twice from a 1:1 water-ethanol mixture, filtered, and dried in vacuo for a further six days to give a final yield of $10.52 \mathrm{~g}$ (83\%): CHN microanalysis, Anal Calcd (found) for $\mathrm{ZnC}_{10} \mathrm{H}_{12} \mathrm{~N}_{2} \mathrm{O}_{8} \cdot \mathrm{Na}_{2} \cdot 2 \mathrm{H}_{2} \mathrm{O}: \mathrm{C}, 27.57$ (27.28); H, 3.70 (3.35); N, 6.43 (6.38). IR $\left(\mathrm{cm}^{-1}\right): \nu(\mathrm{C}-\mathrm{H}) 2950 \mathrm{~m}, v(\mathrm{C}=\mathrm{O}) 1605 \mathrm{vs}, 1400 \mathrm{~s}$, 930s, $v(\mathrm{C}-\mathrm{N}) 1130 \mathrm{~m}$.

Complex 2, Zn-Pr-Pr, N,N'-Dimethyl-N-N'-bis(2-sulfanylpropyl)propylenediamine Zinc(II). The ligand $\mathrm{N} \mathrm{N}^{\prime}$-dimethyl$\mathrm{N}, \mathrm{N}^{\prime}$-bis(2-sulfanylpropyl)propylenediamine was synthesized according to the published procedures [41]. The ligand $(2.390 \mathrm{~g}, 9.56 \mathrm{mmol})$ in $30 \mathrm{~mL}$ of $1: 1$ ethanol-methanol solvent mix was placed in a $200 \mathrm{~mL}$ round bottom flask in an ice bath, under an argon atmosphere, and stirred for $15 \mathrm{~min}$. To this $\mathrm{NaH}(0.500 \mathrm{~g}, 20.83 \mathrm{mmol})$ was added and the solution was stirred for another 20 min under an argon atmosphere. $\mathrm{Zn}(\mathrm{OAc})_{2} \cdot 2 \mathrm{H}_{2} \mathrm{O}$ (1.966 g, $\left.8.96 \mathrm{mmol}\right)$ was dissolved in ethanol $(80 \mathrm{~mL})$ under an argon atmosphere and added dropwise to the ligand. The whole mixture was allowed to stir for $15 \mathrm{hrs}$ and then was concentrated on a rotary evaporator to $80 \mathrm{~mL}$. The solution was filtered through a fine glass frit funnel, and the filtrate further reduced in volume to $50 \mathrm{~mL}$. Diethyl ether $(20 \mathrm{~mL})$ was added to the solution and left in a $-20^{\circ} \mathrm{C}$ freezer overnight. The white colored crystalline precipitate that formed was filtered, washed with diethyl ether, and dried in vacuo to yield $1.72 \mathrm{~g}(61 \%)$ of the zinc product: $\mathrm{CHN}$ microanalysis, Anal Calcd (found) for $\mathrm{ZnC}_{11} \mathrm{H}_{24} \mathrm{~N}_{2} \mathrm{~S}_{2}$ : C, 41.10 (40.48); H, 7.71 (7.15); N, 8.93 (9.22). IR $\left(\mathrm{KBr}, \mathrm{cm}^{-1}\right)$ : $1650,1465,1455,1438,1408,1362,1292,1143$, 1042, 1007, 985.

Complex 3, (Zn(pya $\left.\left.{ }_{2} t n\right) C l_{2}\right), N, N^{\prime}$-Bis(2-pyridylmethylene)1,3-diaminopropyl Zinc(II) Chloride. The complex was synthesized in a manner analogous to that reported for the Ni(II) complex $[42,43]$. The Schiff base ligand (pya $\left.{ }_{2} \mathrm{tn}\right)$ was derived from 2 equivalents of pyridine-2-carboxaldehyde and 1 equivalent of 1,3-diamino-2-propanol in isopropyl alcohol. The zinc complex was made in situ by dropwise addition of the ligand to a hot solution of $\mathrm{ZnCl}_{2}$ ( 1 equivalent) dissolved in absolute ethanol. The very pale yellow solution was concentrated on a rotary evaporator to $80 \mathrm{~mL}$. Upon cooling, a pale yellow colored crystalline material appeared.
This product was filtered, recrystallized from 10:1 waterisopropyl alcohol solvent mixture, and dried in vacuo for eight days to give a yield of $11.26 \mathrm{~g}(58 \%)$ : $\mathrm{CHN}$ microanalysis, Anal Calcd (found) for $\mathrm{ZnC}_{15} \mathrm{H}_{16} \mathrm{~N}_{4} \mathrm{Cl}_{2}$ : C, 46.36 (46.02); $\mathrm{H}$, 4.15 (3.98); N, 14.42 (14.22). IR $\left(\mathrm{cm}^{-1}\right): v(\mathrm{C}-\mathrm{C}, 4$ bands, $\mathrm{m})$ 1590 to $1440, v(\mathrm{C}-\mathrm{N}) 1650 \mathrm{~s}, v(\mathrm{C}-\mathrm{C}) 1010 \mathrm{~s}, \nu(\mathrm{C}-\mathrm{H}) 790 \mathrm{~s}$.

Complex 4, $\left(\mathrm{Zn}\left(\right.\right.$ pya $_{2}$ tn-OH) $\left.\mathrm{Cl}_{2}\right), \mathrm{N}, \mathrm{N}^{\prime}$-Bis(2-pyridylmethylene)1,3-diamino-2-propanol Zinc(II) Chloride. The ligand was synthesized according to the modification of the published procedures $[43,44]$. The Schiff base ligand $\left(\mathrm{pya}_{2} \mathrm{tn}\right)$ was derived from 2 equivalents of pyridine-2-carboxaldehyde and 1 equivalent of 1,3-diamino-2-propanol. The resulting yellow colored oil was crystallized by the addition of absolute ethanol to the neat oil. The zinc complex is made by the addition of the Schiff base ligand dissolved in absolute ethanol to a refluxing solution of $\mathrm{ZnCl}_{2}$ (1 equivalent), absolute ethanol, and 2,2-dimethoxypropane. The solution was then cooled to give a pale-beige colored crystalline material. The product was filtered, recrystallized from 10:1 water-methanol solvent mixture, and dried in vacuo for four days to give a yield of $17.11 \mathrm{~g}$ (71\%): CHN microanalysis, Anal Calcd (found) for $\mathrm{ZnC}_{15} \mathrm{H}_{16} \mathrm{~N}_{4} \mathrm{Cl}_{2} \mathrm{O}: \mathrm{C}, 44.53$ (44.27); H, 3.99 (3.91); N, 13.85 (13.67). IR $\left(\mathrm{cm}^{-1}\right): \nu(\mathrm{C}-\mathrm{C}, 4$ bands $) v(\mathrm{O}-\mathrm{H}) 3400 \mathrm{~s}$ broad, 1600 to $1430, v(\mathrm{C}-\mathrm{N}) 1650 \mathrm{~s}, v(\mathrm{C}-\mathrm{C}) 1000 \mathrm{~s}, \nu(\mathrm{C}-\mathrm{H}) 780 \mathrm{~s}$.

Complex 5, $\mathrm{Zn}$-sal-Ph-Cl , Bis(N-salicylideneaniline) Zinc(II) Chloride. The ligand (5-L) and the zinc complex were synthesized in a manner analogous to that reported for the bis $(\mathrm{N}-$ phenylsalicylaldimine) nickel complex [45-47]. The salicylideneaniline ligand is commercially available from SigmaAldrich; however, for economic reasons, we chose to synthesize the ligand in-house according to generic procedures [ 48 , 49]. In a $100 \mathrm{~mL}$ round bottomed flask, $2.20 \mathrm{~mL}(24.1 \mathrm{mmol})$ of aniline in $25 \mathrm{~mL}$ water was added to $2.95 \mathrm{~mL}$ ( $27.8 \mathrm{mmol})$ of salicylaldehyde in $20 \mathrm{~mL}$ of water. The flask was kept at room temperature and the solution was vigorously stirred for six hours. The yellow colored precipitate that formed was filtered off, washed with ice-cold water, and dried under vacuo to give a yellow colored precipitate, yield $4.32 \mathrm{~g}$ (91\%). The complex was made by dropwise addition of $1.47 \mathrm{~g}(10.8 \mathrm{mmol})$ $\mathrm{ZnCl}_{2}$ in $40 \mathrm{~mL}$ methanol to a mixture of $4.24 \mathrm{~g}(21.6 \mathrm{mmol})$ salicylideneaniline in $40 \mathrm{~mL}$ methanol. The mixture was refluxed for three hours and then cooled. The yellow-orange colored precipitate that formed was filtered off, washed with ethanol, and dried in vacuo, to yield $4.76 \mathrm{~g}$ (83\%) of product: Anal Calcd (found) for $\mathrm{ZnC}_{26} \mathrm{H}_{22} \mathrm{~N}_{2} \mathrm{O}_{2} \mathrm{Cl}_{2}$ : C, 58.84 (59.17); $\mathrm{H}, 4.18$ (4.44); N, 5.28 (5.21). IR $\left(\mathrm{KBr}, \mathrm{cm}^{-1}\right): v(\mathrm{O}-\mathrm{H}) 3430 \mathrm{w}$, $v(\mathrm{C}-\mathrm{H})$ 2910, $v(\mathrm{C}-\mathrm{N}) 1600 \mathrm{~s}, v(\mathrm{C}-\mathrm{C}) 1540 \mathrm{~s}$.

Complex 6, $\mathrm{Zn}$-sal- $\mathrm{NH}_{2}$, Bis(salicylaldehyde hydrazone) Zinc(II). The ligand, the nickel complex, and the zinc complex have been known since the early 1970s [50]. The ligand is commercially available but is custom-synthesized and thus very expensive. The high cost led us to synthesize the ligand in-house, according to generic procedures $[48,50-$ 52]. The synthesis involves a condensation of salicylaldehyde with hydrazine. The reaction is highly exothermic; therefore, the synthesis is carried out via slow addition of a dilute 
solution of the salicylaldehyde to a dilute solution of hydrazine hydrate. The order of addition and dilute nature of the reagents also prevents side-reactions from occurring (i.e., prevents formation of salicylaldehyde azine). The ligand was synthesized by slowly adding $3.30 \mathrm{~mL}(31.1 \mathrm{mmol})$ of salicylaldehyde in $40 \mathrm{~mL}$ of a 1:1 ethanol/water mixture to a stirring solution of $2.15 \mathrm{~mL}$ (about $34 \mathrm{mmol}$ ) of hydrazine hydrate (50-60\% solution) in $40 \mathrm{~mL}$ of water. The solution was then refluxed for an hour, and upon cooling the resulting pale yellow product was filtered off, washed with cold ethanol, and dried in vacuo to give a yield of $4.15 \mathrm{~g}(98 \%)$ product. The complex was made by adding $3.32 \mathrm{~g}(15.1 \mathrm{mmol})$ zinc acetate dihydrate in $40 \mathrm{~mL}$ of a 1:1 dichloromethanemethanol mixture to a stirring solution of the salicylaldehyde hydrazone ligand $(4.12 \mathrm{~g}, 30.3 \mathrm{mmol})$ in $40 \mathrm{~mL}$ methanol. The mixture was refluxed for five hours and then cooled. The bright yellow colored precipitate was filtered off, washed with ethanol and diethyl ether, and then dried in vacuo to give a yield of $3.94 \mathrm{~g}$ (78\%) product: Anal Calcd (found) for $\mathrm{ZnC}_{14} \mathrm{H}_{14} \mathrm{~N}_{4} \mathrm{O}_{2}$ : C, 50.09 (49.77); $\mathrm{H}, 4.20$ (4.39); N, 16.69 (16.62). IR $\left(\mathrm{KBr}, \mathrm{cm}^{-1}\right): \nu(\mathrm{O}-\mathrm{H}) 3505 \mathrm{w}, \nu(\mathrm{N}-\mathrm{H}) 3295 \mathrm{~s}$, $\nu(\mathrm{C}-\mathrm{N}) 1605 \mathrm{~s}, \nu(\mathrm{C}-\mathrm{O}) 1540 \mathrm{~s}$.

Complex 7, $\mathrm{Zn}$-(dien) $2 . \mathrm{ZnCl}_{4}$, [Bis(dien)zinc(II)] Zinc(II) Tetrachloride. The complex was synthesized in a similar manner to that reported in literature [53]. $\mathrm{ZnCl}_{2}(2.181 \mathrm{~g}, 16 \mathrm{mmol})$ in $40 \mathrm{~mL}$ anhydrous methanol was added dropwise to a stirring solution of diethylenetriamine (dien, $1.729 \mathrm{~mL}, 16 \mathrm{mmol}$ ) in $40 \mathrm{~mL}$ anhydrous methanol, at room temperature. The mixture was then heated and stirred at $60^{\circ} \mathrm{C}$ for three hours. Upon cooling, the resulting off-white colored precipitate was filtered and dried in vacuo to yield $3.48 \mathrm{~g}$ (91\%) of product: CHN microanalysis, Anal Calcd (found) for $\mathrm{Zn}_{2} \mathrm{C}_{8} \mathrm{H}_{26} \mathrm{~N}_{6} \mathrm{Cl}_{4}$ : C, 20.06 (19.97); H, 5.47 (6.11); N, 17.55 (17.34). IR $\left(\mathrm{KBr}, \mathrm{cm}^{-1}\right)$ : $v(\mathrm{~N}-\mathrm{H}) 3330 \mathrm{~s}, 3265 \mathrm{~s}, 3225 \mathrm{~s}, v(\mathrm{C}-\mathrm{H}) 2940 \mathrm{~m}, 2882 \mathrm{~m}, v(\mathrm{C}-\mathrm{N})$ 1072s, 1028s.

Complex 8, $\left(\mathrm{Zn}(\mathrm{en})_{3} \mathrm{Cl}_{2} \cdot \mathrm{H}_{2} \mathrm{O}\right)$, Tris(ethylenediamine)-zinc(II) Chloride. The synthesis was based on the published reports $[54,55]$. In a round bottomed flask, under argon and with stirring, $5.83 \mathrm{~mL}(87 \mathrm{mmol})$ ethylenediamine was added to a solution of $\mathrm{ZnCl}_{2}$ (3.95 g, $\left.29.0 \mathrm{mmol}\right)$ in methanol $(60 \mathrm{~mL})$. The mixture was stirred overnight, reduced in volume on a rotary evaporator to $30 \mathrm{~mL}$, and then filtered. The filtrate was allowed to evaporate for two days at room temperature to yield a white colored precipitate, which was filtered, washed with cold ethanol and diethyl ether, and then dried in vacuo: IR $\left(\mathrm{KBr}, \mathrm{cm}^{-1}\right): \nu(\mathrm{N}-\mathrm{H}) 3500$ s broad, 3250s broad, 1600s, $\nu(\mathrm{C}-$ H) $3000 \mathrm{~s}, 1470 \mathrm{~s}, \nu(\mathrm{C}-\mathrm{N}) 1170 \mathrm{~m}, 1060 \mathrm{~s}$.

\section{Results and Discussion}

3.1. Zinc Complexes. The series of small water soluble $\mathrm{Zn}$ (II) complexes (Figure 1) represent molecules that vary in charge (neutral, anionic, and cationic) and degree of hydrophilicity by virtue of the nature of ligands. Complexes $1,6,7$, and 8 have been previously synthesized [40,50,53-55]. The remaining complexes $(2,3,4$, and 5$)$ are novel. All characterization data, including IR spectroscopy, UV-vis spectroscopy, and elemental microanalysis are consistent with the formulations and structures given for each complex.

Complex $\mathbf{1}$ is a dianion, with the $[\mathrm{EDTA}]^{4-}$ chelate coordinating through the two amines and four carboxylates $\left(\mathrm{N}_{2} \mathrm{O}_{4}\right.$ donor ligand) and adopting octahedral geometry. Complexes 2 and 6 are neutral in charge, with a fourcoordinate ligand donor set of $\mathrm{N}_{2} \mathrm{~S}_{2}$ and $\mathrm{N}_{2} \mathrm{O}_{2}$, respectively, and adopt a pseudotetrahedral structure. Complexes 3, 4, and 5 are also neutral in charge. Complexes 3 and $\mathbf{4}$ possess a $\mathrm{N}_{4} \mathrm{Cl}_{2}$ donor ligand set, while Complex 5 contains a $\mathrm{N}_{2} \mathrm{O}_{2} \mathrm{Cl}_{2}$ donor ligand set. Complexes $\mathbf{3}$ and $\mathbf{4}$ adopt an octahedral geometry with the coordinating chlorides trans to each other, similar to related nickel complexes [42-47]. The most significant difference between the Schiff base Complexes 3 and $\mathbf{4}$ is the presence of a hydroxyl group on the $\mathrm{NN}^{\prime}$ propyl strap. It is expected that this additional feature will enhance the solubility of Complex 4 in polar solvents. Complexes 7 and $\mathbf{8}$ are alicyclic dications, each with an $\mathrm{N}_{6}$ donor ligand set and octahedral geometry $[53,55,56]$. Both are very soluble in polar solvents and make for an interesting comparison with Zn complexes that possess planar aromatic rings.

3.2. Absorption and Emission Spectra of Zn Complexes. The absorption spectra for the eight $\mathrm{Zn}$ complexes are shown in Figure 2. No peaks were observed above $375 \mathrm{~nm}$ for these complexes, confirming the absence of any $\mathrm{d}-\mathrm{d}$ transition. Complexes 3-6 possess absorption band(s) in the visible domain, leading to the observed yellow coloration of these compounds. These bands between $215 \mathrm{~nm}$ and $325 \mathrm{~nm}$ correspond to intraligand $\pi \rightarrow \pi^{*}$ and $n \rightarrow \pi^{*}$ transitions, stemming from the phenyl or pyridyl conjugated rings [57]. Complexes 3, 4, and 6 have measurable absorbance around $280 \mathrm{~nm}$, with Complexes 3 and 4 being the strongest absorbers (molar extinction coefficient, $\varepsilon_{280} \approx 10,000$ to $\left.15,000 \mathrm{M}^{-1} \mathrm{~cm}^{-1}\right) . \varepsilon_{280} \approx 700 \mathrm{M}^{-1} \mathrm{~cm}^{-1}$ for Complex $\mathbf{6}$, while the other complexes have extinction coefficients at this wavelength lower than $150 \mathrm{M}^{-1} \mathrm{~cm}^{-1}$.

Characterization of the absorption spectra is important for two reasons. First, there may be the possibility of coexcitation of the complex when the protein (or Trp) is excited at $280 \mathrm{~nm}$ for fluorescence experiments. Second, if there is an overlap between the emission spectra of the proteins and $\operatorname{Trp}$ and the complex, Forster's long-range energy transfer (FRET) may occur. In order to determine whether or not coexcitation of the complex would require spectral corrections, the fluorescence spectra of each of the eight complexes were obtained following excitation at $280 \mathrm{~nm}$, as shown in Figure 3(a).

With the exception of Complex 5 (solid line), none of the complexes emitted at $345 \mathrm{~nm}$, including the complexes that exhibited strong absorption at $280 \mathrm{~nm}$ (Complexes 3, 4, and 6). It is worth noting that the highest concentration of each Zn complex added in an experimental series was $2.1 \times 10^{-5} \mathrm{M}$. Therefore, the contribution to the fluorescence intensity when the proteins (and Trp) were excited in the presence of the complex was very small (Figure 3(b)).

Given that Complexes 3, 4, and 6 exhibited strong absorption at $280 \mathrm{~nm}$ and Complex $\mathbf{5}$ was emitted weakly at $345 \mathrm{~nm}$, this could affect the absorption and subsequent emission by the proteins (and Trp) and a correction for 


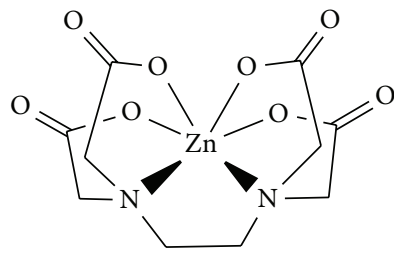

1
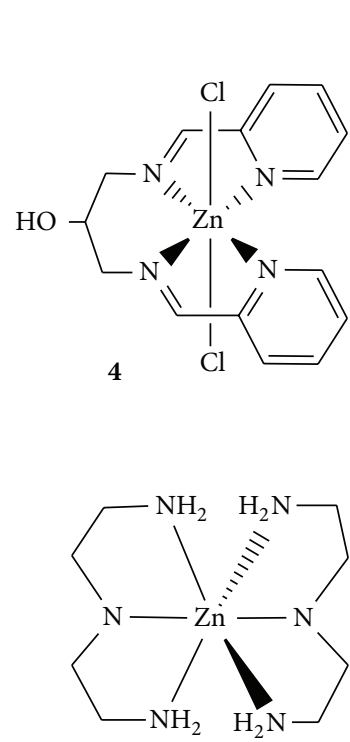
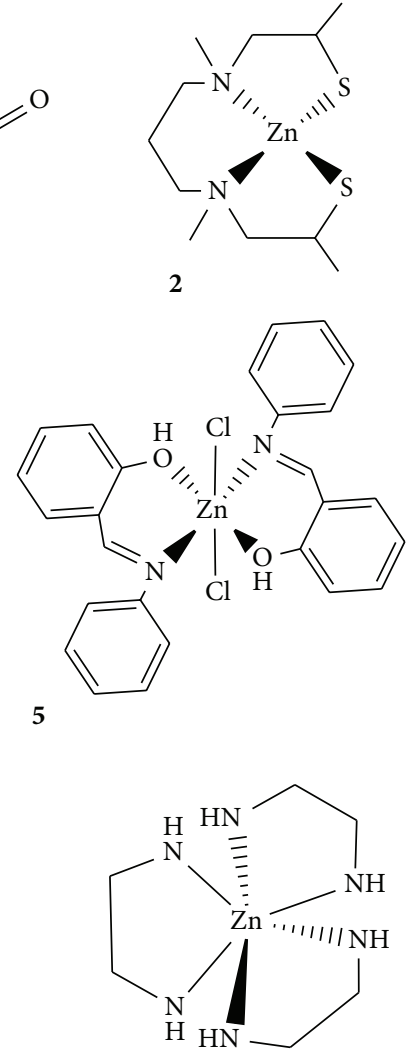

8

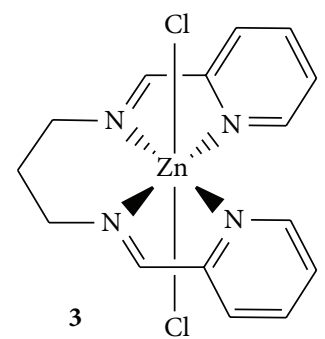<smiles>N/N=C\c1ccccc1O[Z17]12[nH][nH][n+]1=Cc1ccccc1O2</smiles>

6

Figure 1: $\mathrm{Zn}(\mathrm{II})$ complexes used in this study: Complex $\mathbf{1}$ is a dianion; Complexes 2-6 are neutral; Complexes $\mathbf{7}$ and $\mathbf{8}$ are dications.

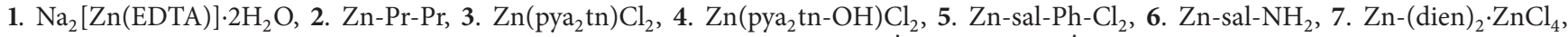
and 8. $\mathrm{Zn}(\mathrm{en})_{3} \cdot 2 \mathrm{Cl} \cdot \mathrm{H}_{2} \mathrm{O}$ [EDTA = ethylenediaminetetraacetate, $\mathrm{Pr}-\mathrm{Pr}=\mathrm{N}, \mathrm{N}^{\prime}$-dimethyl-N, $\mathrm{N}^{\prime}$-bis(2-sulfanylpropyl)propylenediamine, tn $=$ trimethylenediamine, pya $=$ Schiff base ligand derived from pyridine-2-carboxaldehyde and 1,3-diaminopropane $\left(\right.$ pya $\left._{2} \mathrm{tn}\right)$, sal- $\mathrm{Ph}=\mathrm{N}-$ salicylideneaniline, sal- $\mathrm{NH}_{2}=$ salicylaldehyde hydrazine, dien = diethylenetriamine, and en = ethylenediamine $]$.

the inner-filter effect would become necessary. However, the correction is really not necessary if the absorbance of the complex is less than 0.02, which is the case for Complex 6 over the range of concentrations used in this study [58]. For Complexes 3 and 4, the absorbance exceeds 0.02 and the observed fluorescence, $F_{\mathrm{obs}}$, was corrected for the inner-filter effect using the following equation $[34,59]$ :

$$
F_{\text {corr }}=F_{\text {obs }} \times 10^{\left(\mathrm{OD}_{280}+\mathrm{OD}_{345}\right) / 2}
$$

the corrected fluorescence intensity, $F_{\text {corr }}$, was determined by taking into account the absorbance value of the quencher at $280 \mathrm{~nm}\left(\mathrm{OD}_{280}\right)$ and at $345 \mathrm{~nm}\left(\mathrm{OD}_{345}\right)$. The corrected intensity was then used to determine the Stern-Volmer constant $\left(K_{\mathrm{SV}}\right)$ and binding constant $\left(K_{a}\right)$ using (1)-(3). This correction was carried out for all $\mathrm{Zn}$ complexes, including the ones that were weakly absorbent at $280 \mathrm{~nm}$ (and the emission wavelengths).

3.3. Fluorescence Quenching by Zn Complexes. Proteins with different numbers and locations of Trp residues were studied. The observed fluorescence quenching is a result of the interaction between the ligand bound to the $\mathrm{Zn}$ in the complex, the Trp residue(s) of the protein, and its immediate vicinity in the protein. The extent of quenching as determined by a decrease in total fluorescence and calculated binding constants depends on the protein and the nature of the ligand. Three major factors are typically involved in fluorescence quenching: (i) the hydrophobicity of the ligand, (ii) the charge of the complex, and (iii) the immediate environment of the Trp residue in the protein. The globular proteins in this study have complex structures, and so many types of interactions are possible between the protein and the $\mathrm{Zn}$ complex, including van der Waals, electrostatic, hydrophobic, and hydrogen bonding [39].

A typical fluorescence quenching series is shown in Figure 4. BSA has a strong fluorescence emission with a broad peak around $345 \mathrm{~nm}$ upon excitation at $280 \mathrm{~nm}$. The fluorescence intensity of BSA decreases in the presence of Complex 5, indicating a significant interaction between the complex and protein. An isoemissive point was observed at $410 \mathrm{~nm}$ and the emission intensity increased with complex concentration at $450 \mathrm{~nm}$. This phenomenon has no effect on the quenching of the protein and the interaction leading to the quenching. There is no shift in the emission maximum of 


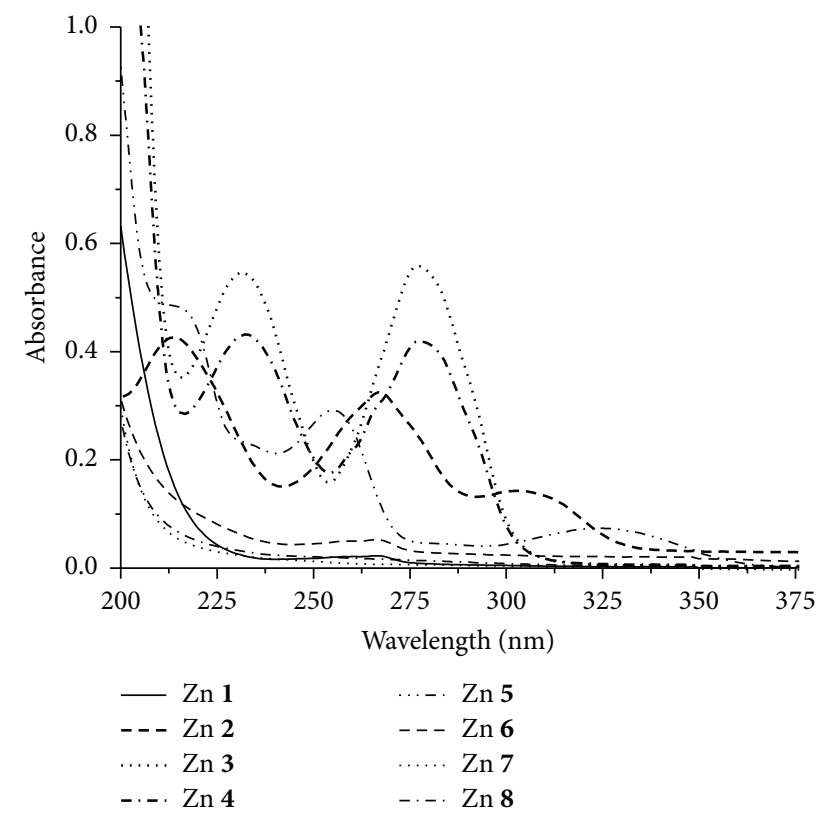

FIgURE 2: Absorption spectra of the eight zinc complexes. Samples were at $3.0 \times 10^{-4} \mathrm{M}$, with the exception of Complexes 3 and $\mathbf{4}$, which were measured at $3.0 \times 10^{-5} \mathrm{M}$.

TABLE 1: Percent decrease in fluorescence intensity of fluorophore $\left(1.0 \times 10^{-5} \mathrm{M}\right)$ at the highest quencher concentration $(21 \mu \mathrm{M})$ at $25^{\circ} \mathrm{C}$. Fluorescence intensity was measured at $345 \mathrm{~nm}$.

\begin{tabular}{lcccc}
\hline & $\mathbf{3}$ & $\mathbf{4}$ & $\mathbf{5}$ & $\mathbf{6}$ \\
\hline BSA & 21.8 & - & 29.6 & $4.29^{1}$ \\
HSA & 19.6 & 16.0 & 34.6 & - \\
Lyso & 23.7 & 15.2 & 11.0 & - \\
Trp & - & 39.1 & - & - \\
Charge & 0 & 0 & 0 & 0 \\
\hline
\end{tabular}

${ }^{1}$ Decrease at $1.8 \times 10^{-5} \mathrm{M}$. Quenching reversed at quencher concentrations higher than $1.8 \times 10^{-5} \mathrm{M}$.

the proteins (and Trp) when they were quenched by Complexes $3,4,5$, and $\mathbf{6}$. The degree of fluorescence quenched in each of the combinations of fluorophore and $\mathrm{Zn}$ complex studied is summarized in Table 1.

The Zn Complexes 1, 2, 7, and 8 did not quench the fluorescence of any protein or free Trp. These complexes are nonaromatic and possess no planar structural features. Complexes 1, 7, and 8 adopt octahedral geometry, and Complex 2 adopts tetrahedral geometry. The complexes do vary in charge: Complex $\mathbf{1}$ is a dianion, Complexes $\mathbf{7}$ and $\mathbf{8}$ are dications, and Complex $\mathbf{2}$ is neutral. The overall trend in the type of complexes that quench these proteins and Trp and those that do not is similar to the data obtained from a series of small $\mathrm{Ni}$ (II) complexes, where complexes with aromatic ligands displayed very strong interactions, and the nonaromatic nickel complexes showed no affinity towards the proteins [41].

The quenching of BSA by Complex 6 proceeded to a lesser extent than all other combinations. With this complex, quenching was reversed at concentrations higher than
$1.8 \times 10^{-5} \mathrm{M}$, which can be explained using Le Chatelier's Principle, where the equilibrium shifts to the reactants when an excess of the complex is formed. As discussed later, the quenching was predominantly static in nature and due to the formation of a nonfluorescent complex. Equation (7) illustrates the equilibrium reaction:

$$
\text { Protein }+\mathrm{Zn} \text { complex } \longleftrightarrow \text { Protein-Zn complex] }
$$

In the case of free Trp, only Complex 4 was found to be interacting. This complex, in addition to the planar aromatic features, possess hydroxyl $\left(-\mathrm{OH}\right.$ or $\left.-\mathrm{NH}_{2}\right)$ groups that are capable of $\mathrm{H}$-bonding interactions with the Trp residues. While Complex 6 features readily accessible amines $\left(-\mathrm{NH}_{2}\right)$ that are capable of forming significant H-bonding contacts, this complex only weakly interacted with BSA. The structural features of the ligand itself are important when considering these protein-complex interactions, particularly when there is a possibility of forming $\mathrm{H}$-bonds with Trp and other amino acid residues within the immediate protein environment. It appears that the environment around Trp is also a significant factor, since the $\mathrm{Zn}$ complexes interacted more readily with the proteins when compared to just free Trp.

The results reported here clearly show that aromatic complexes with planar structural features have a very high affinity for these globular proteins and free Trp, whereas nonaromatic complexes with octahedral geometry fail to interact with these systems via the Trp environment. The interaction is more likely if the complexes are neutral. Interestingly, ligands, such as $\mathrm{N}, \mathrm{N}^{\prime}$-dimethyl-N-N'-bis(2sulfanylpropyl)propylenediamine, that generate small square planar complexes, with $\mathrm{Ni}(\mathrm{II})$, for instance, interact to a much greater extent [41], but when in tetrahedral geometry (in 2, e.g.) the complexes fail to interact with the proteins studied.

The underlying mechanism of the interaction of $\mathrm{Zn}$ complexes with these proteins was studied by measuring the intrinsic fluorescence intensity of protein before and after the addition of the complexes. Quenching can be classified as either dynamic or static quenching. Static quenching occurs as a result of the formation of a relatively less-fluorescent ground state complex between the fluorophore and the quencher, whereas dynamic quenching results from a collisional process between the fluorophore and the quencher. In order to determine the fluorescence quenching mechanism, the Stern-Volmer equation was used to process the collected data. A plot of $F_{0} / F$ against [quencher] is typically linear when dynamic quenching occurs ((1) and (2)) as is usually the case for gas-phase and liquid-phase systems, where $k_{q}$ or $\tau_{0}$ is large. In the case of the proteins and free $\operatorname{Trp}, \tau_{0}$ is expected to be small $\left(10^{-8}\right.$ to $\left.10^{-9} \mathrm{~s}\right)[41,60]$.

There are three approaches taken to distinguish between static quenching and dynamic quenching. First, for dynamic quenching, the maximum value of $k_{q}$ is around $2.0 \times$ $10^{10} \mathrm{M}^{-1} \mathrm{~s}^{-1}[38,61,62]$. Second, an indication that the quenching may be static is the upward curvature in dynamic quenching plots $[24,30,60]$. Thirdly, if both the binding constant, $K_{a}$, and the bimolecular quenching constant, $k_{q}$, decrease with temperature, then the quenching is taken to be static. For the $\mathrm{Zn}$ complexes investigated, values for $k_{q}$ were in 
TABLE 2: Summary of the Stern-Volmer constant, $K_{\mathrm{SV}}$, and the bimolecular quenching constant, $k_{q}$, for BSA, HSA, lysozyme, and free Trp.

\begin{tabular}{lcccccccc}
\hline Complex & \multicolumn{2}{c}{ BSA } & \multicolumn{2}{c}{ HSA } & \multicolumn{2}{c}{ Lysozyme } & \multicolumn{2}{c}{ Free Trp } \\
$K_{\mathrm{SV}} / \mathrm{M}^{-1}$ & $k_{q} / \mathrm{M}^{-1} \mathrm{~s}^{-1}$ & $K_{\mathrm{SV}} / \mathrm{M}^{-1}$ & $k_{q} / \mathrm{M}^{-1} \mathrm{~s}^{-1}$ & $K_{\mathrm{SV}} / \mathrm{M}^{-1}$ & $k_{q} / \mathrm{M}^{-1} \mathrm{~s}^{-1}$ & $K_{\mathrm{SV}} / \mathrm{M}^{-1}$ & $k_{q} / \mathrm{M}^{-1} \mathrm{~s}^{-1}$ \\
$\left(\times 10^{4}\right)$ & $\left(\times 10^{12}\right)$ & $\left(\times 10^{4}\right)$ & $\left(\times 10^{12}\right)$ & $\left(\times 10^{4}\right)$ & - & - \\
\hline $\mathbf{3}$ & 1.3 & 1.3 & 1.4 & 1.4 & 1.5 & 1.5 & 3.0 \\
$\mathbf{4}$ & - & - & 0.94 & 0.94 & 0.69 & 0.69 & - \\
$\mathbf{5}$ & 2.0 & 2.0 & 2.4 & 2.4 & 0.62 & 0.62 & - \\
$\mathbf{6}$ & 0.22 & 0.22 & - & - & - & - & - \\
\hline
\end{tabular}

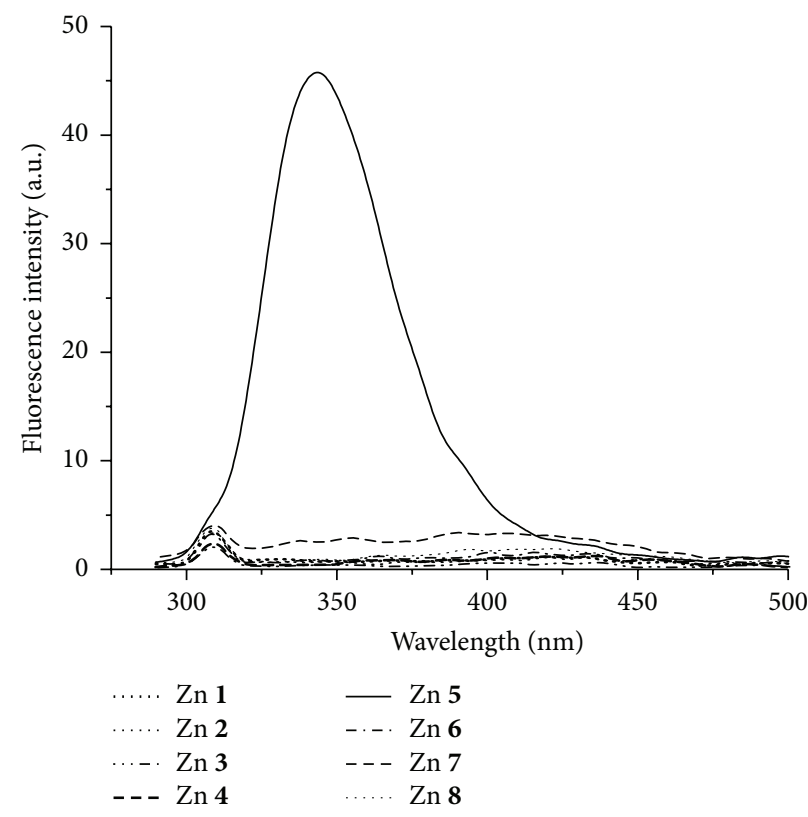

(a)

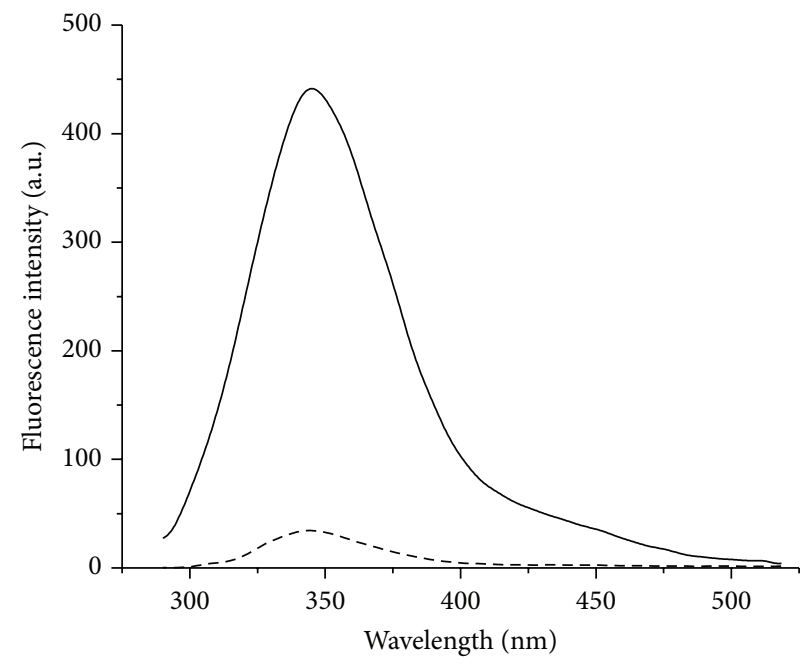

-- - Zn 5

- BSA

(b)

Figure 3: (a) Emission spectra of the eight Zn complexes $\left(3.0 \times 10^{-5} \mathrm{M}\right)$. (b) Emission spectra of BSA $\left(1.0 \times 10^{-5} \mathrm{M}\right)$ and Complex $5(2.1 \times$ $\left.10^{-5} \mathrm{M}\right) . \lambda_{\text {exc }}=280 \mathrm{~nm}$. Excitation and emission slit widths were both set at $4.0 \mathrm{~nm}$.

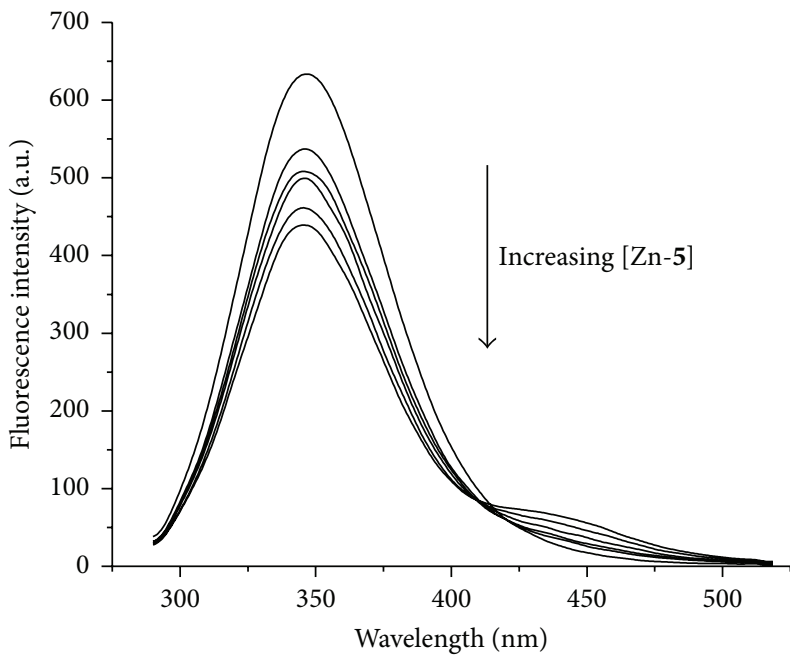

FIGURE 4: Typical fluorescence quenching spectra, showing quenching of BSA by Complex 5 over a concentration range of 0.0 to $21.0 \mu \mathrm{M}$ of the complex. An isoemissive point was observed at $410 \mathrm{~nm}$. the order of $10^{11}$ to $10^{12} \mathrm{M}^{-1} \mathrm{~s}^{-1}$, as summarized in Table 2. In the case of similar $\mathrm{Ni}(\mathrm{II})$ complexes, values for $k_{q}$ were found to be in the order of $10^{12}$ to $10^{13} \mathrm{M}^{-1} \mathrm{~s}^{-1}$ [41]. The dynamic quenching plots for these complexes (not shown) displayed very slight upward curvature at high complex concentrations, thus lowering the $R^{2}$ values. Similar upward curvature has been observed with complexes containing nickel as well as chromium(III) and molybdenum(VI) [60, 63]. Finally, both the binding constants and Stern-Volmer constants decreased with temperature, as described in a later section. These observations clearly show that static quenching predominates due to the formation of a ground state complex between the protein and $\mathrm{Zn}$ complex.

For static quenching, the apparent binding constant $\left(K_{a}\right)$ for the interaction between the $\mathrm{Zn}$ complexes and proteins was determined using double logarithmic plots based on (3), and the results are summarized in Table 3 . The value of $n$ is associated with binding constant and implies a direct relation between the binding constant and number of binding sites. The data illustrates that smaller complexes (such as $\mathbf{3}, \mathbf{4}$, and 5) exhibit moderate to strong binding interactions with HSA 
TABLE 3: Summary of binding constant, $K_{a}$, binding site number, $n$, and $\Delta G$ for BSA, HSA, lysozyme, and free tryptophan at $25^{\circ} \mathrm{C}$.

\begin{tabular}{lcccccccccccc}
\hline \multirow{2}{*}{ Complex } & \multicolumn{3}{c}{$\mathrm{BSA}$} & \multicolumn{3}{c}{$\mathrm{HSA}$} & \multicolumn{3}{c}{ Lysozyme } & \multicolumn{3}{c}{ Free Trp } \\
& $K_{a} / \mathrm{M}^{-1}$ & $n$ & $\Delta G / \mathrm{kJ} \mathrm{mol}^{-1}$ & $K_{a} / \mathrm{M}^{-1}$ & $n$ & $\Delta G / \mathrm{kJ} \mathrm{mol}^{-1}$ & $K_{a} / \mathrm{M}^{-1}$ & $n$ & $\Delta G / \mathrm{kJ} \mathrm{mol}^{-1}$ & $K_{a} / \mathrm{M}^{-1}$ & $n$ & $\Delta G / \mathrm{kJ} \mathrm{mol}^{-1}$ \\
\hline $\mathbf{3}$ & $1.2 \times 10^{5}$ & 1.0 & -29 & $7.7 \times 10^{10}$ & 2.5 & -56 & $6.2 \times 10^{4}$ & 1.0 & -27 & - & - & - \\
$\mathbf{4}$ & - & - & - & $2.0 \times 10^{6}$ & 2.5 & -66 & $3.7 \times 10^{4}$ & 1.0 & -26 & $1.2 \times 10^{5}$ & 1.0 \\
$\mathbf{5}$ & $1.1 \times 10^{6}$ & 1.0 & -35 & $5.0 \times 10^{6}$ & 1.5 & -38 & $1.7 \times 10^{7}$ & 2.0 & -41 & -29 & - & - \\
$\mathbf{6}$ & $9.6 \times 10^{4}$ & 1.0 & -28 & - & - & - & - & - & - & - & - \\
\hline
\end{tabular}

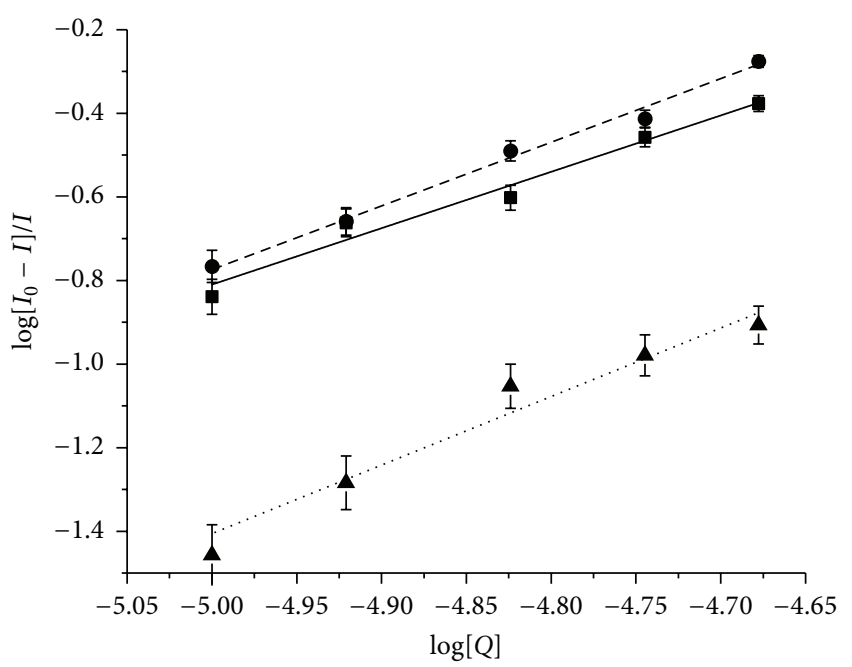

Figure 5: The Stern-Volmer plots for the static quenching of BSA $(\boldsymbol{\square})$, HSA ( $)$, and lysozyme $(\boldsymbol{\Delta})$ by Complex $\mathbf{5}$ at $25^{\circ} \mathrm{C} . R^{2}$ values: BSA 0.974, HSA 0.986, and lysozyme 0.965 .

and lysozyme. Static quenching plots for the three proteins with Complex $\mathbf{5}$ are shown in Figure 5.

The calculated $K_{a}$ values correlate extremely well with the extent of fluorescence quenching. There is also a strong correlation between $K_{a}$ and the large negative values obtained for $\Delta G$, as shown in Table 3 . The calculated $\Delta G$ values confirm that binding is a spontaneous process and are similar to values observed in other studies involving BSA, HSA, and lysozyme $[17,39,41,60,61,64-66]$.

The absence of any significant binding and quenching between BSA and lysozyme with complexes such as $\mathbf{4}$ (with BSA) and 6 (with lysozyme) is most likely due to the $\mathrm{H}$ bonding interactions that arise from the presence of a $-\mathrm{OH}$ group in $\mathbf{4}$ and $-\mathrm{NH}_{2}$ groups in $\mathbf{6}$. This results in significantly strong interactions between the complex and the polar amino acids in the immediate vicinity of the Trp residue(s) in the protein.

3.4. Nature of the Interaction between the Proteins and $\mathrm{Zn}$ Complexes. The observed fluorescence emission of these proteins arises from Trp, tyrosine (Tyr), and phenylalanine (Phe) residues. Phe has a very low quantum yield, and the fluorescence of Tyr is almost totally quenched when it is ionized or close to an amino group, a carboxyl group, or a Trp. Thus, the fluorescence of these proteins is dominated by $\operatorname{Trp}$ emission. Fluorescence quenching of Trp residues occurs when there is significant interaction with hydrophobic ligands, which is either promoted or stabilized by additional amino acid residues in the immediate environment $[41,66]$. BSA has two tryptophan residues: Trp-134 residue is near the surface of the protein surrounded by negatively charged (Glu), polar uncharged (Ser), and hydrophobic (Tyr, Val) amino acid residues. Trp-212 is in a hydrophobic pocket and surrounded by hydrophobic residues (Tyr, Leu, and Phe). HSA contains a lone Trp-214 found in a pocket, surrounded by only hydrophobic residues (Tyr, Val). In lysozyme, there are six tryptophans in various environments, some of which are surrounded by positively charged amino acids (Lys, Arg) [62].

The interaction of $\mathrm{Zn}$ complexes with free Trp is relatively strong $\left(K_{a}>10^{5} \mathrm{M}^{-1}\right)$ but is limited to Complex 4. This $\mathrm{Zn}$ complex possesses functional groups that can $\mathrm{H}$-bond to Trp and/or possess a highly labile ligand. H-bonding can lead to a very strong interaction overall; such nonhydrophobic contacts are thermodynamically favored and play a major role in generating the high $K_{a}$ values. For Complex 4, there is a possibility that monodentate chloride ligands are displaced in aqueous solution, which would allow free Trp to interact directly with the $\mathrm{Zn}$ atom through the nucleophilic $\mathrm{O}$ and/or $\mathrm{N}$ donor atoms.

The interaction with lysozyme is limited to the octahedral Complexes 3, 4, and 5. A variety of interactions are possible between lysozyme and 3: Trp-28, Trp-62, Trp-63, and Trp111 residues are close to amphiphilic amino acids, such as Lys and Arg, while Trp-108 and Trp-123 residues are close to hydrophobic Val and Ile, respectively. Complex 3 is comprised of planar aromatic ligands, with minimal flexibility in the equatorial plane due to the five membered chelate rings, and, unlike Complex 4, there is no possibility of forming $\mathrm{H}$ bond contacts with Trp or nearby residues. The result is strong and significant interactions with lysozyme.

Complexes 3 and $\mathbf{4}$ are both similar in structure except for the $\mathrm{OH}$ group on the ligand of 4 . Both are octahedral in geometry with the two chlorides in the axial positions and neutral in charge. Both complexes bind to HSA, but only 3 binds to BSA. This observation is similar to what was observed with the analogous nickel complexes [41]. Trp-134 in BSA has a polar amino acid (Ser) in its vicinity. It is possible that a H-bonding interaction could be occurring between this residue and Complex 4, in addition to the $\mathrm{H}$-bonding involving Trp. The H-bonding interaction is stronger than any stacking interaction that would be expected between Tyr (or Trp) and the pyridinium group(s) in the complex. The $\mathrm{H}$ bonding between the $\mathrm{OH}$ group in Complex 4 and the Ser (and/or Trp) residue is also stronger than the hydrophobic 
interactions promoted by the Leu and Val residues in the vicinity of Trp-134 [62]. This situation also results in the absence of fluorescence quenching when Complex 4 is added to BSA. However, BSA does have an additional residue (Trp212) in a very similar buried hydrophobic environment to the Trp-214 in HSA. This Trp-212 residue has no polar residues in its immediate vicinity, and so one might expect some fluorescence quenching to occur albeit reduced in the case of BSA, though why no quenching was detected remains unclear. HSA does not have polar residues near its Trp214 , so the hydrophobic interactions predominate, leading to fluorescence quenching and strong binding. The binding of Complex 4 to HSA $\left(K_{a} \sim 10^{6}\right)$ is weaker than that of Complex $3\left(K_{a} \sim 10^{10}\right)$, providing a binding site number of 1.5 , which could be due to an interaction between Complex 4 with a nearby tyrosine residue, through either stacking or hydrogen bonding.

The values for the number of binding sites $(n)$ varied from 1 to 2.5, as calculated from (3). In the case of BSA, the values for $n$ were all equal to 1.0. This indicates that there is one set of binding sites in the proximity of the fluorophore in BSA for $\mathrm{Zn}$ complexes and that the key contact is predominantly a hydrophobic interaction. For interactions with HSA, the value of $n$ ranged from 1.5 to 2.5 for the strongly binding Complex $3\left(K_{a}=7.7 \times 10^{10} \mathrm{M}^{-1}\right)$. A binding site number of 1.0 is typical when static quenching of proteins occurs as a result of hydrophobic interactions alone. The presence of two binding sites in HSA raises the possibility that multiple quencher complexes may be involved and that nonhydrophobic forces have a very important role to play in these close contacts.

The temperature dependence of the $K_{a}$ and $k_{q}$ values indicates the nature of quenching. The $K_{a}$ values can also be used to determine the signs of enthalpy and entropy changes that occur during association of the fluorophore with quencher. The decrease in the binding constants indicates that the protein-complex interactions are weakening as the temperature is raised. This observation eliminates the dynamic quenching mechanism, since dynamic quenchers do not physically bind to the target, and the Stern-Volmer constant increases with temperature. Thus, the most probable quenching mechanism is initiated by protein-complex formation rather than dynamic collision. For example, with Complex 5, the binding constant $K_{a}$ decreased for BSA, HSA, and lysozyme, but there was no quenching of lysozyme at $45^{\circ} \mathrm{C}$. There was little to no quenching at higher temperatures with Complexes 3, 4, and 6, with the exception of Trp, where quenching occurred at all three temperatures with Complex 4. In the cases where there was little quenching, the bimolecular quenching constant, $k_{q}$, decreased with temperature, which is the opposite of what is expected in the case of dynamic quenching. Van't Hoff plots were generated using (5), and changes in enthalpy $(\Delta H)$ and entropy $(\Delta S)$ were calculated and summarized in Table 4. Van't Hoff plots for BSA and HSA with Complex 5 are presented in Figure 6.

The combination of high $K_{a}$ values $\left(>10^{4} \mathrm{M}^{-1}\right)$ and negative $\Delta H$ values clearly shows that the binding process is highly spontaneous and exothermic. The exothermic interaction is
TABLE 4: Changes in enthalpy $(\Delta H)$ and entropy $(\Delta S)$ for the interaction of the proteins (and Trp) with $\mathrm{Zn}$ complexes.

\begin{tabular}{lcccc}
\hline & \multicolumn{2}{c}{$\mathbf{4}$} & \multicolumn{2}{c}{$\mathbf{5}$} \\
& $\begin{array}{c}\Delta H \\
\mathrm{~kJ} \mathrm{~mol}^{-1}\end{array}$ & $\begin{array}{c}\Delta S \\
\mathrm{~J} \mathrm{~mol}^{-1} \mathrm{~K}^{-1}\end{array}$ & $\begin{array}{c}\Delta H \\
\mathrm{~kJ} \mathrm{~mol}^{-1}\end{array}$ & $\begin{array}{c}\Delta S \\
\mathrm{~J} \mathrm{~mol}^{-1} \mathrm{~K}^{-1}\end{array}$ \\
\hline BSA & - & - & -175 & -468 \\
HSA & - & - & -207 & -564 \\
Lysozyme $^{1}$ & - & - & -150 & -365 \\
Trp & -244 & -716 & - & - \\
\hline
\end{tabular}

${ }^{1}$ Lysozyme did not quench at $45^{\circ} \mathrm{C}$ so the data is based on measurements at $25^{\circ} \mathrm{C}$ and $35^{\circ} \mathrm{C}$ only.

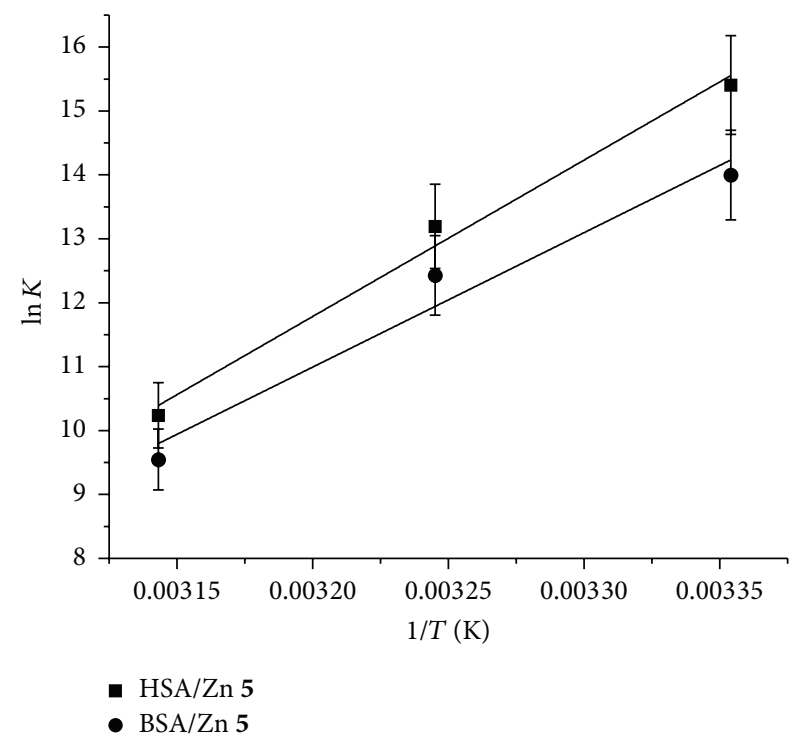

Figure 6: Van't Hoff plots for BSA and HSA with Complex 5. $R^{2}$ values: BSA 0.9631, HSA 0.9896.

consistent with "bond formation" or binding, which results in the product being lower in energy. This data also confirms that the binding weakens with increasing temperature and the value for $K_{a}$ decreases. According to Le Chatelier's principle, exothermic reactions favor reactants as the temperature increases. Negative values for both $\Delta H$ and $\Delta S$ show that the interaction between these $\mathrm{Zn}$ complexes and the proteins is a result of van der Waals forces and $\mathrm{H}$-bonding and drives the reaction forward [61]. Wu and coworkers reported negative entropy values for HSA and a positive entropy value for BSA $[38,67]$. In our previous study with a dioxo-Mo(VI) complex, negative values for both $\Delta H$ and $\Delta S$ for BSA, HSA, lysozyme, and tryptophan were reported [63].

The possibility of Forster's long-range resonance energy transfer (FRET), which occurs over a distance of 2-10 nm, was investigated. In order for this type of quenching to occur, the emission spectrum of the donor (protein or Trp) must have some overlap with the absorption spectrum of the acceptor ( $\mathrm{Zn}$ complex). The absorption spectra of Complexes 5 and 6 do display (Figure 2 and highlighted in Figure 7) some overlap with the emission spectra of the proteins and Trp. 
TABLE 5: Summary of the FRET analysis for the overlap $(J)$ between the absorption spectrum of Complexes $\mathbf{5}$ and $\mathbf{6}$ and the emission spectra of BSA, HSA, and lysozyme and the Forster distance $\left(R_{0}\right)$ for the combinations that showed fluorescence quenching.

\begin{tabular}{lcccc}
\hline & \multicolumn{2}{c}{5} & \multicolumn{2}{c}{$\mathbf{6}$} \\
& $J\left(\mathrm{~L} \cdot \mathrm{cm}^{3} / \mathrm{mol}\right)$ & $R_{0}(\mathrm{~nm})$ & $J\left(\mathrm{~L} \cdot \mathrm{cm}^{3} / \mathrm{mol}\right)$ & $R_{0}(\mathrm{~nm})$ \\
\hline BSA & $1.46 \times 10^{-15}$ & 1.73 & $5.89 \times 10^{-16}$ & 1.49 \\
HSA & $1.49 \times 10^{-15}$ & 1.74 & - & - \\
Lysozyme & $4.87 \times 10^{-16}$ & 1.26 & - & - \\
\hline
\end{tabular}

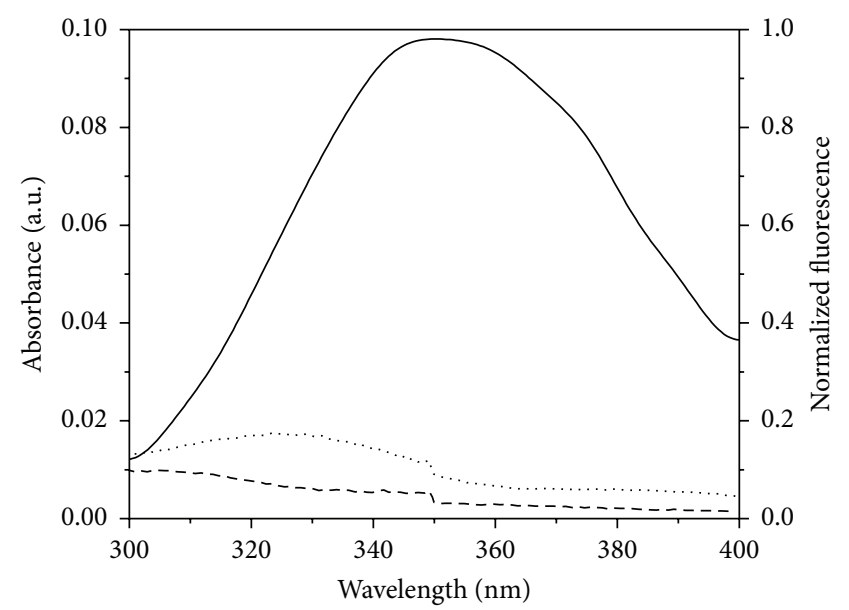

FIGURE 7: Fluorescence emission spectrum of $1.0 \times 10^{-5} \mathrm{M}$ BSA (solid line) and the absorption spectra of $1.0 \times 10^{-5} \mathrm{M}$ Complex 5 (dotted line) and Complex 6 (dashed line) showing minor spectral overlap.

The spectral overlap integral between the protein emission and complex absorbance was calculated to be in the order of $10^{-15}-10^{-16} \mathrm{~L} \cdot \mathrm{cm}^{3} \cdot \mathrm{mol}^{-1}$ due to the low molar absorptivity of these complexes, and Forster distances $\left(r_{0}\right.$, the distance at which $50 \%$ energy transfer occurs) are less than $2 \mathrm{~nm}$ (Table 5); thus, one can rule out quenching due to FRET. Taking the temperature dependence and magnitude of $k_{q}$, it is clear that static quenching is predominant in these systems. The Forster distances are in good agreement with what we have reported for the dioxo-Mo(VI) complex and with other reports in the literature $[39,63]$.

Molecular modeling studies (Gaussian, Docking) are currently underway to pinpoint and determine optimal binding and the energetic contribution that accompanies the interaction between Trp residues and their protein environment in HSA, BSA, and lysozyme with this series of $\mathrm{Zn}$ complexes.

\section{Conclusion}

The synthesis and characterization of a series of $\mathrm{Zn}$ (II) complexes with different types of ligands containing N, S, and $\mathrm{O}$ donor atoms are reported. Fluorescence spectroscopy and Stern-Volmer kinetics were used to study the interaction of the $\mathrm{Zn}$ complexes with human and bovine serum albumin and lysozyme proteins. The addition of the complexes causes the intrinsic fluorescence of Trp residues to quench by varying amounts depending on the nature of complex. The Zn complexes possessing planar aromatic ligands exhibit exceptionally strong interactions and much greater fluorescence quenching, particularly with the Trp residues located in hydrophobic environments. Static quenching was found to be the predominant form of quenching in these systems, generating binding constants over a wide range $\left(10^{4}-\right.$ $\left.10^{10} \mathrm{M}^{-1}\right)$. The thermodynamic parameters, as estimated from the Stern-Volmer plots and Gibbs' free energy values, suggest that the binding of $\mathrm{Zn}$ complexes to the proteins is a highly spontaneous process. In the case of BSA the binding reaction was mainly driven by hydrophobic interactions. For HSA, lysozyme, and free Trp, the thermodynamic parameters suggest a combination of forces at play. The fluorescence studies described may provide an approach in evaluating the molecular mechanism of metal-based chemicals on serum proteins.

\section{Conflict of Interests}

The authors declare that there is no conflict of interests regarding the publication of this paper.

\section{Acknowledgments}

The authors thank Susquehanna University and Centenary College for the financial support for this project.

\section{References}

[1] D. W. Christianson and C. A. Fierke, "Carbonic anhydrase: evolution of the zinc binding site by nature and by design," Accounts of Chemical Research, vol. 29, no. 7, pp. 331-339, 1996.

[2] G. B. Rao, "Recent developments in the design of specific Matrix metalloproteinase inhibitors aided by structural and computational studies," Current Pharmaceutical Design, vol. 11, no. 3, pp. 295-322, 2005.

[3] C. I. Branden, H. Eklund, B. Nordstrom et al., "Structure of liver alcohol dehydrogenase at 2.9-angstrom resolution," Proceedings of the National Academy of Sciences of the United States of America, vol. 70, no. 8, pp. 2439-2442, 1973.

[4] F. A. Quiocho and W. N. Lipscomb, "Carboxypeptidase a: a protein and an enzyme," Advances in Protein Chemistry, vol. 25, pp. 1-78, 1971.

[5] B. W. Matthews, "Structural basis of the action of thermolysin and related zinc peptidases," Accounts of Chemical Research, vol. 21, no. 9, pp. 333-340, 1988.

[6] C. M. Overall and C. López-Otín, "Strategies for MMP inhibition in cancer: innovations for the post-trial era," Nature Reviews Cancer, vol. 2, no. 9, pp. 657-672, 2002.

[7] M. M. Yamashita, L. Wesson, G. Eisenman, and D. Eisenberg, "Where metal ions bind in proteins," Proceedings of the National Academy of Sciences of the United States of America, vol. 87, no. 15, pp. 5648-5652, 1990.

[8] T. Dudev and C. Lim, "Principles governing Mg, Ca, and $\mathrm{Zn}$ binding and selectivity in proteins," Chemical Reviews, vol. 103, no. 3, pp. 773-788, 2003.

[9] I. L. Alberts, K. Nadassy, and S. J. Wodak, "Analysis of zinc binding sites in protein crystal structures," Protein Science, vol. 7, no. 8, pp. 1700-1716, 1998. 
[10] H. Vorum, K. Fisker, and B. Honoré, "Palmitate and stearate binding to human serum albumin: determination of relative binding constants," Journal of Peptide Research, vol. 49, no. 4, pp. 347-354, 1997.

[11] G. Zolese, G. Falcioni, E. Bertoli et al., "Steady-state and time resolved fluorescence of albumins interacting with $\mathrm{N}$-oleylethanolamine, a component of the endogenous $\mathrm{N}$ acylethanolamines," Proteins: Structure, Function and Genetics, vol. 40, no. 1, pp. 39-48, 2000.

[12] J.-P. Laussac and B. Sarkar, "Characterization of the copper(II)and nickel(II)-transport site of human serum albumin. Studies of copper(II) and nickel(II) binding to peptide 1-24 of human serum albumin by $13 \mathrm{C}$ and $1 \mathrm{H}$ NMR spectroscopy," Biochemistry, vol. 23, no. 12, pp. 2832-2838, 1984.

[13] W. Bal, J. Christodoulou, P. J. Sadler, and A. Tucker, "Multimetal binding site of serum albumin," Journal of Inorganic Biochemistry, vol. 70, no. 1, pp. 33-39, 1998.

[14] P. Gosling, "Albumin and the critically ill," Care Critically, vol. 11, pp. 57-61, 1995.

[15] T. Peters Jr., "Serum albumin," Advances in Protein Chemistry, vol. 37, pp. 161-245, 1985.

[16] T. Peters, All about Albumin: Biochemistry, Genetics and Medical Applications, Academic Press, San Diego, Calif, USA, 1995.

[17] J. Tian, J. Liu, X. Tian, Z. Hu, and X. Chen, "Study of the interaction of kaempferol with bovine serum albumin," Journal of Molecular Structure, vol. 691, no. 1-3, pp. 197-202, 2004.

[18] A. Sułkowska, J. Równicka, B. Bojko, and W. Sułkowski, "Interaction of anticancer drugs with human and bovine serum albumin," Journal of Molecular Structure, vol. 651-653, pp. 133140, 2003.

[19] Y. Li, W. He, J. Liu, F. Sheng, Z. Hu, and X. Chen, "Binding of the bioactive component Jatrorrhizine to human serum albumin," Biochimica et Biophysica Acta-General Subjects, vol. 1722, no. 1, pp. 15-21, 2005.

[20] Y.-Q. Wang, H.-M. Zhang, G.-C. Zhang, W.-H. Tao, Z.-H. Fei, and Z.-T. Liu, "Spectroscopic studies on the interaction between silicotungstic acid and bovine serum albumin," Journal of Pharmaceutical and Biomedical Analysis, vol. 43, no. 5, pp. 1869-1875, 2007.

[21] I. D. Kuntz, "Structure-based strategies for drug design and discovery," Science, vol. 257, no. 5073, pp. 1078-1082, 1992.

[22] N. Latha and B. Jayaram, "A binding affinity based computational pathway for active-site directed lead molecule design: Some promises and perspectives," Drug Design Reviews Online, vol. 2 , no. 2, pp. 145-165, 2005.

[23] M. R. Eftink and C. A. Ghiron, "Dynamics of a protein matrix revealed by fluorescence quenching," Proceedings of the National Academy of Sciences of the United States of America, vol. 72, no. 9, pp. 3290-3294, 1975.

[24] M. R. Eftink and C. A. Ghiron, "Fluorescence quenching studies with proteins," Analytical Biochemistry, vol. 114, no. 2, pp. 199227, 1981.

[25] M. Eftink, "Quenching-resolved emission anisotropy studies with single and multitryptophan-containing proteins," Biophysical Journal, vol. 43, no. 3, pp. 323-334, 1983.

[26] T. Imoto, L. S. Forster, J. A. Rupley, and F. Tanaka, "Fluorescence of lysozyme: emissions from tryptophan residues 62 and 108 and energy migration," Proceedings of the National Academy of Sciences of the United States of America, vol. 69, no. 5, pp. 1151$1155,1972$.
[27] T. Imoto, L. N. Johnson, A. T. C. North, D. C. Phillips, and J. A. Rupley, Lysozyme in Enzymes, Academic Press, New York, NY, USA, 1972.

[28] M. J. Kronman and L. G. Holmes, "The fluorescence of native, denatured and reduced-denatured proteins," Photochemistry and Photobiology, vol. 14, no. 2, pp. 113-134, 1971.

[29] S. S. Lehrer, "Solute perturbation of protein fluorescence. The quenching of the tryptophyl fluorescence of model compounds and of lysozyme by iodide ion," Biochemistry, vol. 10, no. 17, pp. 3254-3263, 1971.

[30] C. Formoso and L. S. Forster, "Tryptophan fluorescence lifetimes in lysozyme," The Journal of Biological Chemistry, vol. 250, no. 10 , pp. $3738-3745,1975$.

[31] A. J. Gordon and R. A. Ford, The Chemist's Companion, John Wiley \& Sons, New York, NY, USA, 1972.

[32] J. A. Riddick, W. B. Bunger, and T. K. Sakano, Organic Solvents, John Wiley \& Sons, New York, NY, USA, 1986.

[33] C. M. Schneck, A. J. Poncheri, J. T. Jennings, D. L. Snyder, J. L. Worlinsky, and S. Basu, "Competition between solvent quenching and indole quenching of 9-fluorenone: a spectroscopic and computational study," Spectrochimica Acta A: Molecular and Biomolecular Spectroscopy, vol. 75, no. 2, pp. 624-628, 2010.

[34] J. R. Lakowicz, Principles of Fluorescence Spectroscopy, Springer Science \& Business Media, New York, NY, USA, 2004.

[35] J. S. Johansson, "Binding of the volatile anesthetic chloroform to albumin demonstrated using tryptophan fluorescence quenching," The Journal of Biological Chemistry, vol. 272, no. 29, pp. 17961-17965, 1997.

[36] R. Swaminathan, G. Krishnamoorthy, and N. Periasamy, "Similarity of fluorescence lifetime distributions for single tryptophan proteins in the random coil state," Biophysical Journal, vol. 67, no. 5, pp. 2013-2023, 1994.

[37] H. M. Rawel, S. K. Frey, K. Meidtner, J. Kroll, and F. J. Schweigert, "Determining the binding affinities of phenolic compounds to proteins by quenching of the intrinsic tryptophan fluorescence," Molecular Nutrition and Food Research, vol. 50, no. 8, pp. 705-713, 2006.

[38] D. Wu, Q. Wei, Y. Li, B. Du, and G. Xu, "Quenching of the intrinsic fluorescence of bovine serum albumin by phenylfluorone$\mathrm{Mo}(\mathrm{VI})$ complex as a probe," International Journal of Biological Macromolecules, vol. 37, no. 1-2, pp. 69-72, 2005.

[39] J. B. Xiao, J. W. Chen, H. Cao et al., "Study of the interaction between baicalin and bovine serum albumin by multispectroscopic method," Journal of Photochemistry and Photobiology A: Chemistry, vol. 191, no. 2-3, pp. 222-227, 2007.

[40] D. T. Sawyer and P. J. Paulsen, "Properties and infrared spectra of ethylenediaminetetraacetic acid complexes. II. Chelates of divalent ions," Journal of the American Chemical Society, vol. 81, no. 4, pp. 816-820, 1959.

[41] H. F. Crouse, J. Potoma, F. Nejrabi, D. L. Snyder, B. S. Chohan, and S. Basu, "Quenching of tryptophan fluorescence in various proteins by a series of small nickel complexes," Dalton Transactions, vol. 41, no. 9, pp. 2720-2731, 2012.

[42] D. C. Weatherburn, E. J. Billo, J. P. Jones, and D. W. Margerum, "Effect of ring size on the stability of polyamine complexes containing linked consecutive rings," Inorganic Chemistry, vol. 9, no. 6, pp. 1557-1559, 1970.

[43] T. G. Campbell and F. L. Urbach, "Synthesis and characterization of nickel(II) complexes of neutral, tetradentate Schiff base ligands derived from 1,3-diamines," Inorganic Chemistry, vol. 12, no. 8, pp. 1836-1840, 1973. 
[44] G. S. Smith and J. L. Hoard, "The structure of dihydrogen ethylenediaminetetraacetatoaquonickel(II)," Journal of the American Chemical Society, vol. 81, no. 3, pp. 556-561, 1959.

[45] P. Pfeiffer, E. Breith, E. Lübbe, and T. Tsumaki, "Tricyclische orthokondensierte Nebenvalenzringe," Justus Liebig's Annalen der Chemie, vol. 503, no. 1, pp. 84-130, 1933.

[46] F. Basolo and W. R. Matoush, "Changes in configuration of some nickel(II) complexes," Journal of the American Chemical Society, vol. 75, no. 22, pp. 5663-5666, 1953.

[47] G. N. Tyson Jr. and S. C. Adams, "The configuration of some cupric, nickelous and cobaltous complexes by means of magnetic measurements," Journal of the American Chemical Society, vol. 62, no. 5, pp. 1228-1229, 1940.

[48] A. Simion, C. Simion, T. Kanda et al., "Synthesis of imines, diimines and macrocyclic diimines as possible ligands, in aqueous solution," Journal of the Chemical Society. Perkin Transactions 1, pp. 2071-2078, 2001.

[49] A. Hantzsch and O. Schwab, "Zur kenntniss der condensationsproducte aus aldehyden und aminen," Berichte der Deutschen Chemischen Gesellschaft, vol. 34, no. 1, pp. 822-839, 1901.

[50] R. C. Aggarwal, N. K. Singh, and R. P. Singh, "Synthesis and structural studies of some first row transition metal complexes of salicylaldehyde hydrazone," Inorganica Chimica Acta, vol. 32, no. C, pp. L87-L90, 1979.

[51] E. C. Okafor, "On the condensation of salicylaldehyde with hydrazine," Talanta, vol. 25, no. 4, pp. 241-242, 1978.

[52] M. P. Jain and S. Kumar, "Condensation of some substituted salicylaldehydes with hydrazine," Talanta, vol. 26, no. 9, pp. 909-910, 1979.

[53] R.-B. Xu, X.-Y. Xu, P.-F. Shi et al., "Synthesis and crystal structure of a new complex [bis(dien)zinc(II)] zinc(II) tetrachloride (dien = diethylenetriamine)," Chinese Journal Structural Chemistry, vol. 26, no. 12, pp. 1441-1444, 2007.

[54] L. Cheng, Y.-Y. Sun, Y.-W. Zhang, and G. Xu, "Tris(ethylenediamine)zinc(II) dichloride monohydrate," Acta Crystallographica Section E: Structure Reports Online, vol. 64, no. 10, Article ID m1246, 2008.

[55] C. Muralikrishna, C. Mahadevan, S. Sastry, M. Seshasayee, and S. Subramanian, "Structure of tris(ethylenediamine)zinc(II) chloride dihydrate, $\left[\mathrm{Zn}\left(\mathrm{C}_{2} \mathrm{H}_{8} \mathrm{~N}_{2}\right)_{3}\right] \mathrm{Cl}_{2} \cdot 2 \mathrm{H}_{2} \mathrm{O}$," Acta Crystallographica, vol. 39, pp. 1630-1632, 1983.

[56] S. Zhicheng, Y. Zhiming, A. Lata, and H. Yuhua, "Serum angiotensin converting enzyme, ceruloplasmin, and lactic dehydrogenase in anthracosilicosis and anthracosilicotuberculosis," British Journal of Industrial Medicine, vol. 43, no. 9, pp. 642-643, 1986.

[57] A. B. P. Lever, Inorganic Electronic Spectroscopy, Elsevier Science, Amsterdam, The Netherlands, 2nd edition, 1984.

[58] I. E. Borissevitch, "More about the inner filter effect: corrections of Stern-Volmer fluorescence quenching constants are necessary at very low optical absorption of the quencher," Journal of Luminescence, vol. 81, no. 3, pp. 219-224, 1999.

[59] O. Dömötör, T. Tuccinardi, D. Karcz, M. Walsh, B. S. Creaven, and É. A. Enyedy, "Interaction of anticancer reduced Schiff base coumarin derivatives with human serum albumin investigated by fluorescence quenching and molecular modeling," Bioorganic Chemistry, vol. 52, pp. 16-23, 2014.

[60] H. F. Crouse, E. M. Petrunak, A. M. Donovan, A. C. Merkle, B. L. Swartz, and S. Basu, "Static and dynamic quenching of tryptophan fluorescence in various proteins by a chromium (III) complex," Spectroscopy Letters, vol. 44, no. 5, pp. 369-374, 2011.
[61] D. Wu, B. Du, H. Ma, Q. Wei, and G. Xu, "Quenching of the intrinsic fluorescence of human serum albumin by trimethoxyphenylfluorone-Mo(VI) complex," Spectroscopy Letters, vol. 39, no. 4, pp. 399-408, 2006.

[62] K.-I. Sugae and B. Jirgensons, "Amino acid sequence next to tryptophan in human and bovine serum albumin," Journal of Biochemistry, vol. 56, no. 5, pp. 457-464, 1964.

[63] A. A. Rhodes, B. L. Swartz, E. R. Hosler et al., "Static quenching of tryptophan fluorescence in proteins by a dioxomolybdenum(VI) thiolate complex," Journal of Photochemistry and Photobiology, vol. 293, pp. 81-87, 2014.

[64] Q. Wei, D. Wu, B. Du, Y. Li, and C. Duan, "Interaction of mnitrophenylfluorone-Mo(VI) complex as a probe with human serum albumin: a fluorescence quenching study," Spectrochimica Acta-Part A: Molecular and Biomolecular Spectroscopy, vol. 63, no. 3, pp. 532-535, 2006.

[65] H. Wu, S. Lian, Y. Shen, and Y. Wan, "Interactions of lysozyme with 6-amino-4-aryl-3-methyl-1-phenyl-1H-pyrazolo[3,4b]pyridine-5-carbonitriles: a fluorescence quenching study," Analytical Sciences, vol. 23, no. 4, pp. 419-422, 2007.

[66] S. H. Laurie and D. E. Pratt, "A spectroscopie study of nickel(II)bovine serum albumin binding and reactivity," Journal of Inorganic Biochemistry, vol. 28, no. 4, pp. 431-439, 1986.

[67] C.-Q. Jiang, M.-X. Gao, and J.-X. He, "Study of the interaction between terazosin and serum albumin: synchronous fluorescence determination of terazosin," Analytica Chimica Acta, vol. 452, no. 2, pp. 185-189, 2002. 

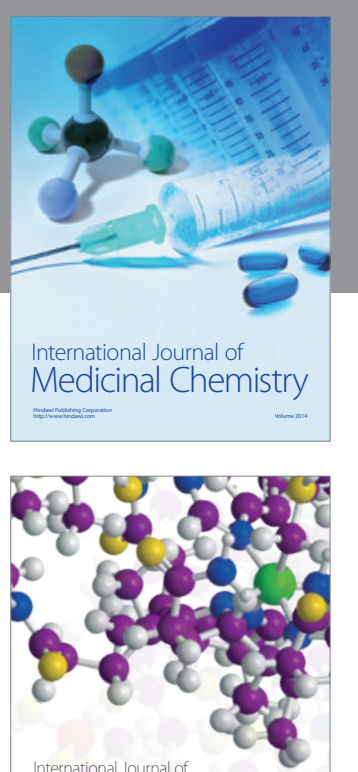

Carbohydrate Chemistry

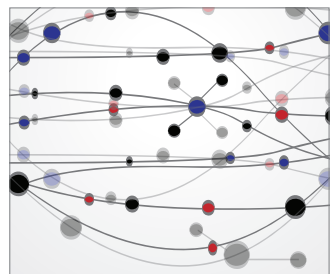

The Scientific World Journal
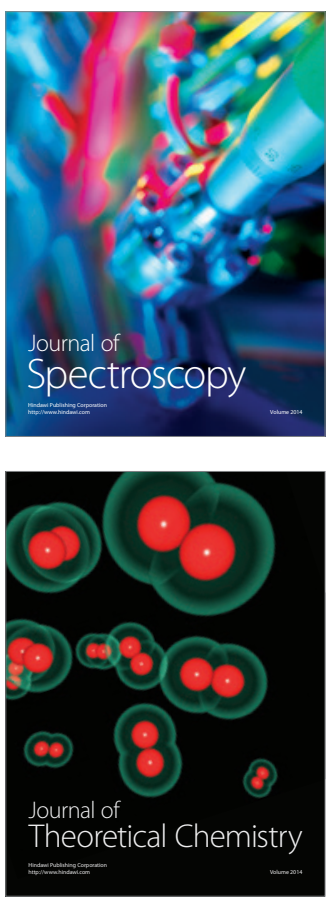
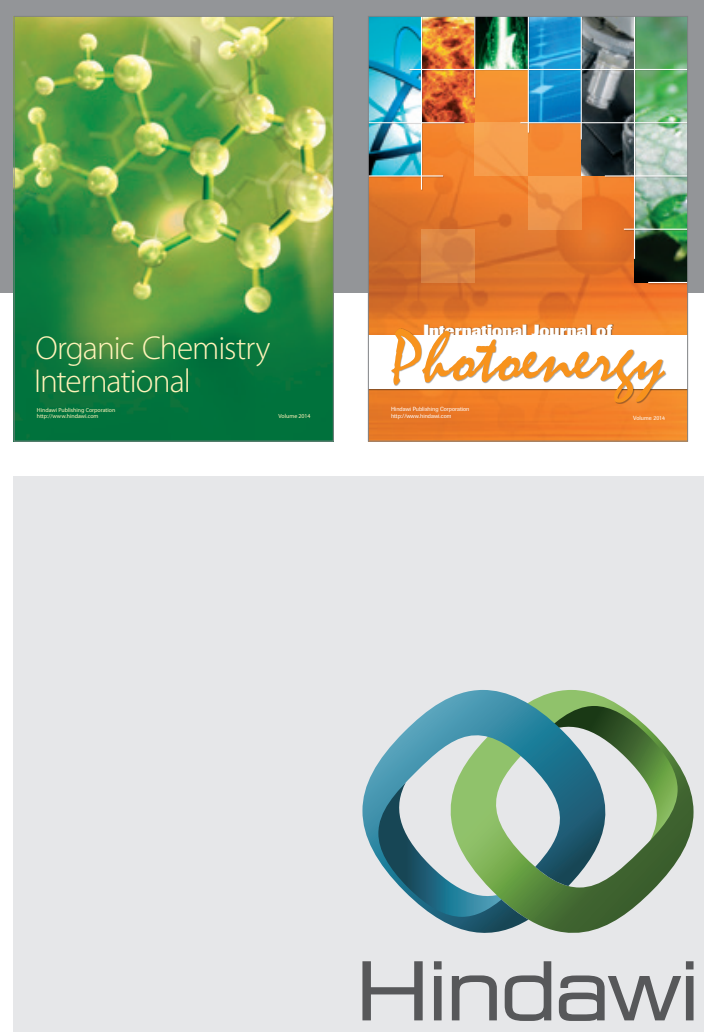

Submit your manuscripts at

http://www.hindawi.com

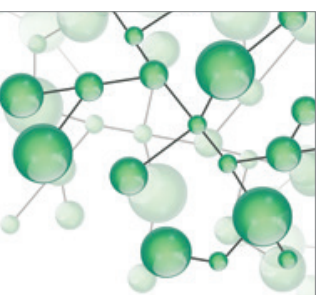

International Journal of

Inorganic Chemistry

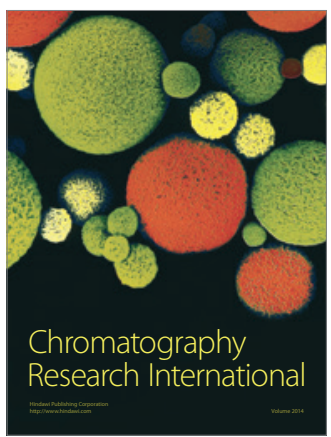

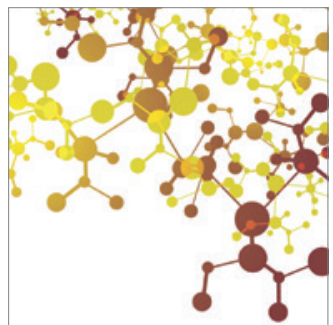

Applied Chemistry
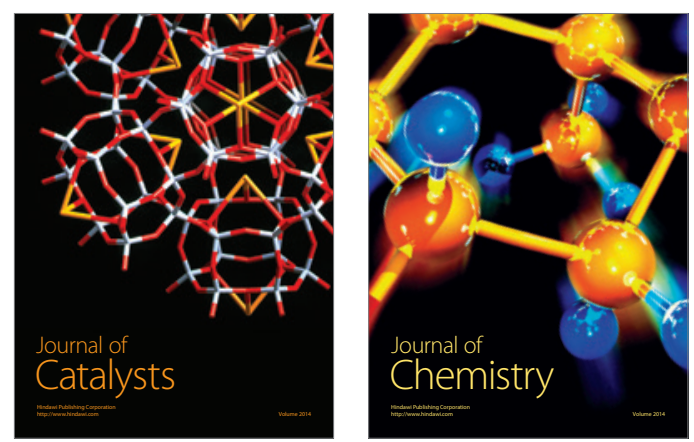
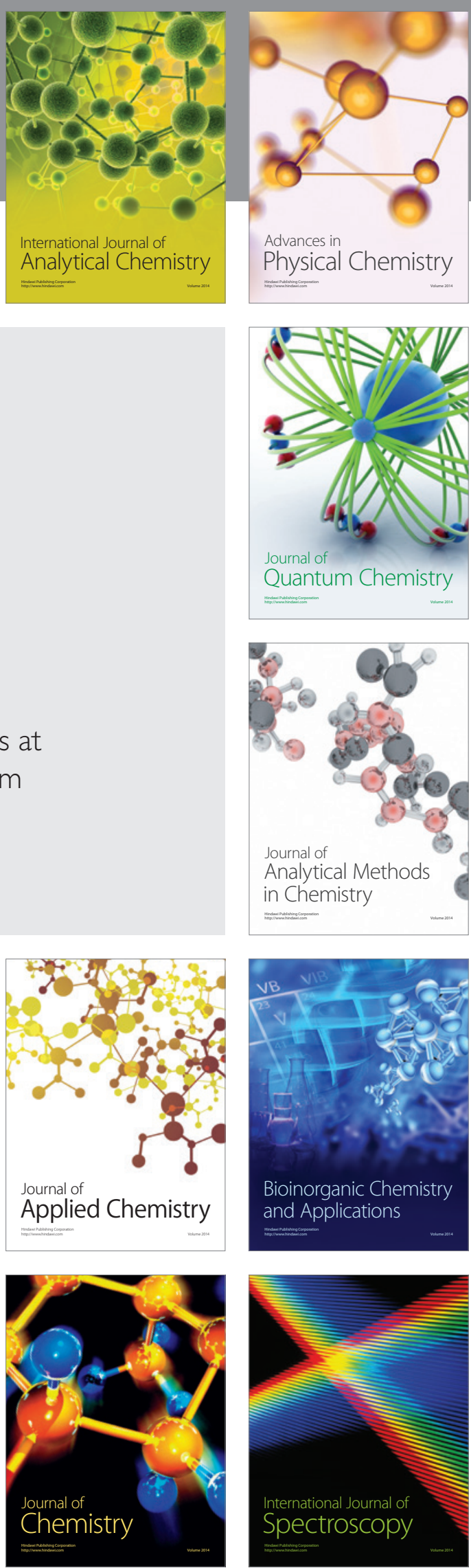